\title{
PENEMUAN MAKNA HIDUP PADA INSAN PASCA STROKE
}

\author{
Adjeng Pudji Rachmawati ${ }^{1}$ \\ Fakultas Psikologi dan Pendidikan \\ Universitas Al Azhar Indonesia \\ Jl. Sisingamangaraja, Kebayoran Baru, \\ Jakarta 12110, Indonesia \\ le-mail: adjengpudji.r@gmail.com
}

\begin{abstract}
This study aims to potrayal of the meaning of life post-stroke human being. The process of the invention the meaning of life was divided into five stages: suffering phase, self-acceptance phase, meaning the discovery phase, meaning the realization phase, and meaningful life phase. In the discovery phase of the meaning of life in it contains the source of meaning in life in the form of creative values, experiental values, attitudinal values, and hopes values. In addition, it also discusses the factors that influence of post-stroke human beings find meaning in life. The approach used in this study is qualitative approach that aims to obtain a thorough and complete understanding of the cases. Data collected methods used were observation and in-depth interviews. The study involved three people over the age of post-stroke human being 45-54 years who suffered paralysis as a research subject. Based on the results of the analysis showed that all three subjects suffer physically and mentally. But only two subjects who can change the condition of the suffering becomes meaningful appreciation of life. The existence of the values obtained from the suffering becomes an important source for the subject in the meaning of life. The implications of this study are expected, human beings can better interpret post-stroke life by doing activities that can support the healing process for the family and can continue to provide guidance and motivation to the human being in order to achieve post-stroke recovery.
\end{abstract}

Keywords: Meaning of life; post-stroke survivor.

\begin{abstract}
Abstrak - Penelitian ini bertujuan untuk melihat gambaran penemuan makna hidup pada insan pasca stroke. Proses penemuan makna hidup, tersusun ke dalam lima tahapan yaitu diawali tahap derita, tahap penerimaan diri, tahap penemuan makna, tahap realisasi makna, dan diakhiri tahap kehidupan bermakna. Selain itu dibahas pula mengenai faktor-faktor apa saja yang memengaruhi insan pasca stroke dalam menemukan makna hidup. Pendekatan yang digunakan pada penelitian ini adalah pendekatan kualitatif yang bertujuan untuk mendapatkan pemahaman secara menyeluruh dan utuh dari kasus yang ada. Metode pengumpulan data yang digunakan adalah observasi dan wawancara mendalam (depthinterview). Subjek pada penelitian ini melibatkan tiga orang insan pasca stroke yang berusia 45-54 tahun yang mengalami kelumpuhan. Berdasarkan hasil analisis yang diperoleh
\end{abstract}


menunjukkan bahwa ketiga subjek mengalami penderitaan secara fisik dan mental. Tetapi hanya dua subjek yang dapat mengubah kondisi penderitaan tersebut menjadi penghayatan kehidupan yang bermakna (meaningfull). Adanya nilai-nilai yang diperoleh dari proses penderitaan menjadi sumber penting bagi subjek dalam menemukan makna hidup. Implikasi dari penelitian ini diharapkan, insan pasca stroke dapat lebih memaknai hidupnya dengan cara melakukan kegiatan yang dapat menunjang proses penyembuhan dan bagi keluarga dapat terus memberikan pendampingan dan motivasi kepada insan pasca stroke demi tercapainya kesembuhan.

Kata kunci: Penemuan makna hidup; insan pasca stroke.

\section{PENDAHULUAN}

Stroke dapat menyerang setiap orang, stroke tidak mengenal gender, usia, ataupun kondisi sosial seseorang. Berdasarkan data Yayasan Stroke Indonesia tahun 2003, tercatat 1,55\% dari 193 orang yang terserang stroke berada di usia muda. Namun, bagaimana jadinya jika stroke terjadi pada individu dewasa tengah? Stroke yang terjadi pada individu usia dewasa madya dapat menghambat produktivitas dan aktivitas kehidupannya (Papalia, Olds, \& Feldman, 2009). Di mana seseorang akan mengalami banyak perubahan seperti yang tadinya bisa berjalan, keesokan harinya setelah terkena stroke membuat pasien tidak lagi bisa berjalan. Di usia dewasa madya ini, baik untuk lelaki atau perempuan mempunyai tugas yang berat di kehidupannya. Bagi para lelaki, terkena stroke sering kali membuat mereka harus kehilangan pekerjaan dan tidak lagi bisa menjadi tumpuan keluarga.

Sedangkan bagi para wanita, terkena stroke menjadi salah satu hambatan mereka untuk mengurus anak-anak yang mulai beranjak dewasa, mengurus rumah beserta dengan segala keperluannya, tidak lagi bisa berkumpul dengan tetangga atau lingkungan sekitar, dan kehilangan tanggung jawab sebagai ibu rumah tangga. Berbagai tekanan inilah yang dapat memperburuk keadaan pasien jika mereka tidak dapat mengubah keadaan tersebut menjadi lebih bermakna. Individu yang mengalami suatu keadaan setelah terdiagnosa stroke disebut dengan insan pasca stroke.

Kondisi ketidakberdayaan yang harus dijalani oleh insan pasca stroke membuat mereka harus mengalami penderitaan baik secara fisik, psikologis, maupun sosial. Sebagai seorang manusia biasa, insan pasca stroke juga ingin menjadi individu yang bisa bertanggung jawab atas dirinya dan bisa berguna untuk keluarga maupun lingkungan di sekitarnya. Hal ini didukung oleh pendapat Frank1 (dalam Bastaman, 2007) bahwa setiap orang mendambakan dirinya sebagai orang yang bertanggung jawab untuk dirinya sendiri, serta menjadi orang yang mampu menentukan sendiri apa yang akan 
dilakukannya dan apa yang paling baik bagi dirinya dan lingkungan. Dari pernyataan tersebut terlihat bahwa hal yang paling mendasar dari setiap manusia sebenarnya adalah hasrat untuk hidup bermakna. Tetapi dengan kondisi ketidakberdayaan yang harus dijalani oleh insan pasca stroke membuat mereka merasa hidupnya menjadi hampa dan tidak bermakna (meaningless).

Insan pasca stroke yang dapat mengubah kondisi dan penghayatan hidupnya dari yang tidak bermakna (meaningless) menjadi bermakna (meaningfull) membutuhkan suatu proses atau tahapan yang perlu dilewati. Bastaman (1996) menjelaskan bahwa ada lima tahapan proses dalam meraih kebermaknaan hidup yaitu tahap derita, tahap penerimaan diri, tahap penemuan makna hidup, tahap realisasi makna, dan tahap kehidupan bermakna. Tetapi tidak semua individu mengalami semua tahapan tersebut, yang terpenting adalah ketika individu dapat menemukan dan memaknai apa yang ada dibalik penderitaan tersebut.

Makna hidup menurut Bastaman (2007) adalah suatu hal yang dianggap sangat penting dan berharga serta memberikan nilai khusus bagi seseorang, sehingga layak dijadikan tujuan dalam kehidupan (the purpose in life). Makna hidup ternyata ada di dalam kehidupan itu sendiri, dan dapat ditemukan dalam setiap keadaan yang menyenangkan dan keadaan yang tak menyenangkan, keadaan bahagia, dan penderitaan. Sedangkan menurut Frankl (2008) mengatakan bahwa makna hidup ini merupakan sesuatu yang unik dan khusus, artinya makna tersebut hanya bisa dipenuhi oleh individu itu sendiri dan hanya dengan cara itulah dia bisa memiliki arti yang bisa memuaskan keinginan individu tersebut untuk mencari makna hidup.

Menurut Bastaman (1996) proses keberhasilan adalah urutan pengalaman dan tahap-tahap kegiatan seseorang dalam mengubah penghayatan hidup tidak bermakna menjadi bermakna berdasarkan urutannya, yaitu:

1. Tahap derita, yaitu pengalaman tragis dan penghayatan hidup tanpa makna. Selain itu, suatu peristiwa tragis dalam hidup seseorang dapat menimbulkan penghayatan hidup tanpa makna yang ditandai dengan perasaan hampa, apatis, bosan, dan merasa tidak lagi memiliki tujuan hidup.

2. Tahap penerimaan diri, individu mulai menerima apa yang terjadi pada hidupnya, pemahaman diri, dan terjadinya perubahan sikap. Munculnya kesadaran diri biasanya didorong oleh berbagai ragam faktor. Misalnya karena perenungan diri, konsultasi dengan para ahli, mendapat pandangan dari seseorang, berdoa, ibadah, belajar dari orang lain, dan lain-lain.

3. Tahap penemuan makna hidup, tahap ini ditandai dengan penyadaran individu akan nilai-nilai berharga yang sangat penting dalam hidupnya. Hal-hal yang dianggap berharga dan penting itu 
mungkin saja berupa nilai-nilai kreatif, nilai-nilai penghayatan, dan nilai-nilai bersikap, dan nilai-nilai pengharapan.

4. Tahap realisasi makna. Pada tahap ini, individu akan mengalami semangat dan gairah dalam hidupnya, kemudian secara sadar melakukan komitmen diri (self-commitment) dan melakukan kegiatan nyata yang lebih terarah guna memenuhi makna hidupnya.

5. Tahap Kehidupan Bermakna. Keberhasilan dalam menemukan dan memenuhi makna hidup akan menyebabkan seseorang merasakan yang berarti dan pada akhirnya akan menimbulkan rasa bahagia.

Ciri-ciri yang dikemukakan Frankl (Schultz dalam Kuncar, 2012) mengenai individu sehat adalah individu yang dapat menemukan makna hidupnya melalui realisasi nilai-nilai manusiawi. Faktor yang memengaruhi makna hidup seseorang terbagi ke dalam dua faktor yaitu faktor internal dan eksternal. Di mana di dalam faktor internal terdapat pola berpikir, pola sikap, konsep diri, kepercayaan, ibadah, dan kepribadian. Sedangkan pada faktor eksternal di dalamnya meliputi pekerjaan, pengalaman, hubungan dalam keluarga, kebudayaan, dan dukungan sosial.

Stroke adalah gangguan saraf yang disebabkan oleh pecahnya pembuluh darah atau adanya gumpalan di pembuluh darah yang mengakibatkan aliran darah ke otak menjadi terganggu sehingga suplai nutrisi dan oksigen yang dibutuhkan oleh otak tidak terpenuhi dengan baik. Hal ini dapat terjadi dikarenakan faktor risiko yang dibiarkan dan tidak ditangani dengan tepat.

Individu yang mengalami suatu keadaan setelah terdiagnosa stroke disebut sebagai insan pasca stroke (Feigin, 2004). Insan pasca stroke juga merupakan kondisi di mana individu kehilangan kendali atas bagian-bagian tertentu dalam tubuh serta pikirannya, hampir semua individu pasca stroke tidak lagi dapat melakukan gerakan yang sempurna pada bagian tubuh tertentu dan individu mengalami kemunduran fungsi fisik dan perubahan pada perilakunya. Sutrisno (2007) menyatakan bahwa kondisi insan pasca stroke mengalami keterbatasan fisik, dan adanya efek psikologis terhadap kondisi cacat yang dialami insan seperti gangguan emosional, perubahan mental, dan akhirnya depresi.

Insan pasca stroke biasanya akan menjadi pribadi yang pemurung, putus asa, sedih, mudah tersinggung dan kecewa. Setelah menyadari kondisi tersebut, insan pasca stroke merasakan dunia ini gelap, semua menjadi percuma. Lalu timbul perasaan menyesal dan bersalah yang muncul dalam bentuk depresi, khawatir, cemas, dan was-was. 
Mereka merasakan perasaan galau yang akan muncul ke permukaan berupa sikap-sikap tidak menyenangkan di lingkungannya. Pada tahap ini, insan pasca stroke akan menjadi kasar, gampang tersinggung, dan ingin segera mati. Padahal pada dasarnya, mati paling ditakutkan dan dihindarinya. Ia menolak pertolongan, membangkang, dan sejumlah perasan lain yang muncul silih berganti.

Depresi dan kecemasan yang merupakan fenomena mental-emosional harus mendapat pertolongan utama (Tirtawati, 2008). Menurut Lubis (dalam Pandji, 2011) mengatakan bahwa stroke memengaruhi semua aspek kehidupan manusia, baik secara fisik, psikologis, sosial, dan kerja.

Berdasarkan uraian di atas, maka peneliti tertarik untuk meneliti penemuan makna hidup yang dilalui oleh insan pasca stroke. Penemuan makna hidup tersebut dapat dilihat dari lima tahapan proses penemuan makna hidup yaitu tahap derita, tahap penerimaan diri, tahap penemuan makna, tahap realisasi makna, dan tahap kehidupan bermakna yang telah dikemukakan oleh Bastaman (1996).

\section{METODE}

\section{Partisipan}

Karakteristik subjek pada penelitian ini adalah: 1) individu lelaki atau perempuan pasca stroke berusia 40 - 65 tahun, 2) menderita stroke baik stroke sumbatan (iskemik) atau stroke pendarahan (hemorargik), 3) baru mengalami serangan stroke atau minimal 2 tahun setelah serangan stroke yang pertama, dan 5) mengalami kelumpuhan, baik setengah anggota badan kiri atau kanan maupun keduanya.

\section{Desain}

Untuk mendapatkan informasi yang lebih lengkap dan menyeluruh, maka peneliti mengambil pendekatan kualitatif. Satu tujuan penting dalam penelitian kualitatif adalah diperolehnya pemahaman menyeluruh dan utuh tentang kasus yang diteliti (Poerwandari, 2013). Metode penelitian yang peneliti ambil adalah metode studi kasus. Alasan peneliti menggunakan metode studi kasus mengacu pada topik penelitian ini yaitu penemuan makna hidup pada insan pasca stroke. Melalui metode ini, diharapkan peneliti dapat mengetahui riwayat hidup subjek, riwayat penyakit stroke subjek, bagaimana tahapan proses yang dilalui subjek dalam menemukan makna hidup, faktor-faktor apa saja yang memengaruhi dalam menemukan makna hidup. 


\section{Prosedur}

Teknik pengumpulan data pada penelitian ini menggunakan observasi, wawancara mendalam. Teknik obervasi yang dilakukan pada penelitian ini adalah observasi berjenis pengamat dengan pencatatan observasi checklist. Sedangkan pendekatan wawancara dengan pedoman umum. Alasan peneliti menggunakan wawancara jenis ini adalah untuk meminimalisir terlewatkannya beberapa hal yang seharusnya ditanyakan pada subjek penelitian. Wawancara dilakukan secara mendalam (in-depth interview) dengan bentuk pertanyaan terbuka (open-ended) yang bersifat fleksibel, dan dilakukan dengan menggunakan pedoman umum wawancara untuk menjaga agar tidak ada hal-hal yang terlewatkan serta agar wawancara yang dilakukan tidak keluar dari tujuan penelitian.

Waktu penelitian ini dimulai dari awal bulan Mei sampai bulan September 2014. Pertemuan dengan masing-masing subjek sebanyak 6-7 kali dan dilakukan sampai data penelitian yang dibutuhkan sudah terpenuhi. Sedangkan lokasi pengambilan data penelitian ini dilakukan di ruang intensif perawatan stroke lantai 3 dan ruang rawat inap A Rumah Sakit Pusat Angkatan Darat Gatot Soebroto Ditkesad. Adapun alamat rumah sakit tersebut berada di Jl. Abdul Rahman Saleh No. 24, Jakarta Pusat. Selain itu, peneliti juga mengambil data penelitian di rumah subjek ketika subjek telah selesai menjalani perawatan di rumah sakit.

Alasan peneliti memilih Rumah Sakit Pusat Angkatan Darat Gatot Soebroto Ditkesad sebagai lokasi pengambilan sampel pada penelitian ini dikarenakan rumah sakit ini merupakan salah satu rumah sakit acuan yang memiliki penanganan lengkap dan cepat untuk perawatan intensif penderita stroke.

\section{Teknik Analisis}

Patton (dalam Poerwandari, 2013) menjelaskan bahwa tidak ada rumus atau aturan-aturan absolut mengenai bentuk analisis di dalam penelitian kualitatif. Beberapa tahapan dalam menganalisis data kualitatif menurut Poerwandari (2013) adalah pertama, organisasi data. Pengolahan dan analisis data sesungguhnya diawali dengan mengorganisasikan data. Untuk memudahkan peneliti memeriksa ketepatan langkah-langkah yang telah atau akan diambil, masing-masing data tidak boleh menaruh data menjadi satu. Oleh karena itu, sangat dianjurkan peneliti menyimpan data dalam bentuk-bentuk berbeda (contoh: dalam bentuk print-out dan dalam disket), dan bila dianggap perlu, memiliki satu salinan cadangan. Kedua, koding dan analisis. Koding merupakan penulisan kode-kode pada materi yang diperoleh. Hal ini dimaksudkan untuk dapat mengatur data secara lengkap dan mendetail 
sehingga data dapat memunculkan gambaran tentang topik yang dipelajari. Tahapan yang ketiga merupakan pengujian terhadap dugaan, lalu tahapan keempat yaitu tahapan interpretasi, dan tahapan yang terakhir adalah penulisan laporan penelitian. Pada tahapan ini peneliti akan menganalisis halhal yang terjadi pada masing-masing subjek serta bagaimana hal tersebut dapat terjadi. Analisis dilakukan pada masing-masing subjek berdasarkan data-data yang diperoleh melalui wawancara, dan observasi. Dalam penulisannya, peneliti akan menguraikan analisis dalam bentuk gambaran hasil observasi dan wawancara yang terbagi ke dalam dua analisis yaitu analisis intrakasus dan analisis interkasus yang berisikan tentang gambaran aktivitas kegiatan subjek, gambaran kehidupan secara umum, gambaran penyakit stroke yang diderita, tahapan penemuan makna hidup subjek, dan analisis interkasus.

\section{HASIL DAN ANALISIS}

Tabel 1.

Analisis Antar Banding Tahapan Makna Hidup

\begin{tabular}{|c|c|c|c|}
\hline $\begin{array}{c}\text { Tahapan Makna } \\
\text { Hidup }\end{array}$ & $\begin{array}{l}\text { Subjek I } \\
\text { (RT) }\end{array}$ & $\begin{array}{l}\text { Subjek II } \\
\text { (WS) }\end{array}$ & $\begin{array}{l}\text { Subjek III } \\
\text { (US) }\end{array}$ \\
\hline Tahap Derita & $\begin{array}{l}\text { Terserang stroke } \\
\text { hemorargik }\end{array}$ & $\begin{array}{l}\text { Terserang stroke non- } \\
\text { hemorargik dengan TIA 2x } \\
\text { berulang }\end{array}$ & Terserang stroke iskemik \\
\hline $\begin{array}{c}\text { Tahap Penerimaan } \\
\text { Diri }\end{array}$ & $\begin{array}{l}\text { 1. Menyadari akan } \\
\text { penerapan pola hidup } \\
\text { yang salah } \\
\text { 2. Terlalu berfokus pada } \\
\text { pekerjaan }\end{array}$ & $\begin{array}{l}\text { 1. Menyadari selama ini } \\
\text { tidak memedulikan } \\
\text { nasehat keluarga } \\
\text { 2. Tidak mengontrol pola } \\
\text { makan }\end{array}$ & $\begin{array}{l}\text { Menyadari bahwa dirinya } \\
\text { tidak lagi bisa menjadi } \\
\text { tumpuan keluarga }\end{array}$ \\
\hline $\begin{array}{l}\text { Tahap Penemuan } \\
\text { Makna Hidup }\end{array}$ & $\begin{array}{l}\text { 1. Hikmah agar menjalani } \\
\text { pola hidup disiplin } \\
\text { 2. Tidak lagi menganggap } \\
\text { sepele sakitnya }\end{array}$ & $\begin{array}{l}\text { Tidak menyia-nyiakan } \\
\text { kembali kesempatan yang } \\
\text { Allah berikan }\end{array}$ & \\
\hline $\begin{array}{c}\text { Tahap Realisasi } \\
\text { Makna }\end{array}$ & $\begin{array}{l}\text { 1. Mengubah pola hidup } \\
\text { disiplin } \\
\text { 2. Melakukan fisioterapi } \\
\text { 3. Berjanji untuk hidup } \\
\text { disiplin }\end{array}$ & $\begin{array}{l}\text { 1. Melakukan terapi } \\
\text { (fisioterapi, terapi } \\
\text { wicara) } \\
\text { 2. Mengontrol pola makan } \\
\text { 3. Menjaga pikiran }\end{array}$ & \\
\hline $\begin{array}{c}\text { Tahap Kehidupan } \\
\text { Bermakna }\end{array}$ & $\begin{array}{l}\text { Penghayatan kehidupan } \\
\text { yang bermakna } \\
\text { (meaningfull) }\end{array}$ & $\begin{array}{l}\text { Penghayatan kehidupan } \\
\text { yang bermakna } \\
\text { (meaningfull) }\end{array}$ & $\begin{array}{l}\text { Penghayatan kehidupan } \\
\text { yang bermakna } \\
\text { (meaningless) }\end{array}$ \\
\hline
\end{tabular}


Tabel 2.

Analisis Antar Banding Sumber Makna Hidup

\begin{tabular}{clll}
\hline Sumber Makna Hidup & \multicolumn{1}{c}{$\begin{array}{c}\text { Subjek I } \\
\text { (RT) }\end{array}$} & \multicolumn{1}{c}{$\begin{array}{c}\text { Subjek II } \\
\text { (WS) }\end{array}$} & \multicolumn{1}{c}{$\begin{array}{c}\text { Subjek III } \\
\text { (US) }\end{array}$} \\
\hline Nilai Kreatif & Tidak ada & $\begin{array}{l}\text { Tetap menjalin komunikasi } \\
\text { dengan saudara dan sahabat }\end{array}$ & Tidak ada \\
Nilai Penghayatan & $\begin{array}{l}\text { Berusaha ikhlas dan bersyukur } \\
\text { menjalani semua proses yang } \\
\text { ada dan tetap memasrahkan } \\
\text { kembali usahanya kepada Tuhan }\end{array}$ & $\begin{array}{l}\text { Bersyukur atas kesempatan } \\
\text { hidup yang Tuhan berikan } \\
\text { kepada subjek dan tidak } \\
\text { menyiakan kesempatan tersebut }\end{array}$ & Tidak ada \\
& $\begin{array}{l}\text { Semangat hidup merupakan } \\
\text { kewajiban agar subjek tidak } \\
\text { terpuruk }\end{array}$ & $\begin{array}{l}\text { Semangat hidup merupakan } \\
\text { hal yang membuat subjek bisa } \\
\text { bangkit }\end{array}$ & Tidak ada \\
& $\begin{array}{l}\text { Berharap bisa kembali sehat } \\
\text { dikarenakan masih ada } \\
\text { tanggung jawab anak dan } \\
\text { pekerjaan }\end{array}$ & $\begin{array}{l}\text { Berharap masih mempunyai } \\
\text { waktu untuk melihat anak } \\
\text { sukses dan menikmati menjadi } \\
\text { nenek kelak }\end{array}$ & Tidak ada \\
\hline
\end{tabular}

Tabel 3.

Tabel Analisis Antar Banding Faktor yang Memengaruhi Makna Hidup

\begin{tabular}{clll}
\hline $\begin{array}{c}\text { Faktor yang Memengaruhi } \\
\text { Makna Hidup }\end{array}$ & \multicolumn{1}{c}{$\begin{array}{c}\text { Subjek I } \\
\text { (RT) }\end{array}$} & \multicolumn{1}{c}{$\begin{array}{c}\text { Subjek II } \\
\text { (WS) }\end{array}$} & \multicolumn{1}{c}{$\begin{array}{c}\text { Subjek III } \\
\text { (US) }\end{array}$} \\
\hline Faktor Internal & Pola sikap, ibadah & $\begin{array}{l}\text { Pola sikap, konsep diri, } \\
\text { ibadah }\end{array}$ & Pola sikap (-) \\
Faktor Eksternal & $\begin{array}{l}\text { Pekerjaan, hubungan } \\
\text { dalam keluarga }\end{array}$ & $\begin{array}{l}\text { Hubungan dalam } \\
\text { keluarga, dukungan } \\
\text { sosial }\end{array}$ & $\begin{array}{l}\text { Pekerjaan (-), dukungan } \\
\text { sosial (-) hubungan } \\
\text { dalam keluarga (-) }\end{array}$ \\
\hline
\end{tabular}

\section{DISKUSI}

Menurut Bastaman (1996) proses keberhasilan adalah urutan pengalaman dan tahap-tahap kegiatan seseorang dalam mengubah penghayatan hidup tidak bermakna menjadi bermakna berdasarkan urutannya. Tahap pertama diawali dengan tahap derita. Pada tahap ini diawali dengan pengalaman tragis yang tiba-tiba mengubah hidup subjek yang kemudian subjek rasakan menjadi penghayatan hidup tanpa makna. Tahapan ini dilalui oleh ketiga subjek dalam penelitian ini di mana subjek menderita penyakit stroke yang berdampak pada kelumpuhan anggota tubuh bagian kanan atau kiri. Kelumpuhan ini yang menjadi salah satu penyebab subjek menderita dikarenakan keterbatasannya untuk bergerak dan sulitnya untuk melakukan kegiatan sehari-hari. 
Tahap kedua dalam proses penemuan makna hidup adalah tahap penerimaan diri. Tahap ini ditandai dengan penerimaan diri, pemahaman diri, dan pengubahan sikap individu dengan kondisi stroke nya saat ini, yang berdampak pada berbagai perubahan yang harus subjek jalani. Tahapan ini dilalui oleh ketiga subjek melalui proses yang memerlukan waktu yang cukup lama dan dengan cara yang berbeda-beda dalam menerima kondisinya tersebut. Pada subjek RT, stroke yang dideritanya saat ini merupakan takdir yang telah ditentukan oleh Allah. Penghayatan inilah yang membuat subjek dapat menerima kondisi stroke nya saat ini.

Sedangkan pemahaman diri subjek RT menyadari bahwa stroke yang dideritanya bukanlah karena kesalahan orang lain melainkan disebabkan oleh pola hidup subjek yang tidak sehat. Tahapan penerimaan diri ini subjek rasakan melalui introspeksi yang subjek lakukan setiap harinya dan diiringi dengan doa kepada Allah. Hal tersebut yang membuat subjek merasa lebih tenang dan mulai mengubah sikap nya.

Tidak jauh berbeda dengan subjek RT, subjek WS juga mulai menerima kondisi stroke nya tersebut jauh sebelum stroke-nya yang ketiga ini. Tetapi pada stroke ketiga ini, WS menemukan pemahaman diri di mana subjek tersadar bahwa dirinya salah dengan sikap keras kepala dan tidak memedulikan perhatian yang diberikan oleh keluarga kepada dirinya yang pada akhirnya membuat WS harus terserang stroke kembali untuk ketiga kalinya.

Berbeda halnya dengan subjek US di mana pada awalnya masih bisa menerima kondisi stroke-nya. Tetapi setelah empat tahun menjalani kondisi stroke dan tidak menemukan perubahan yang signifikan. Kemudian US akhirnya kembali pada kondisi awal yaitu mengalami penghayatan hidup yang tidak bermakna (meaningless) dengan menunjukkan sikap kemarahannya kepada Tuhan.

Selanjutnya tahap ketiga dalam proses penemuan makna hidup adalah tahap penemuan makna. Dalam tahap penemuan makna hidup ini tercakup pula dengan penyadaran individu akan nilai-nilai berharga yang sangat penting dalam hidupnya. Dalam ketiga kasus ditemukan makna hidup yang sama, yaitu keadaan stroke yang dapat membuat subjek menderita tersebut, dipandang sebagai bentuk teguran dan takdir yang harus dijalani oleh ketiganya.

Tetapi pada subjek RT dan WS, penemuan makna hidup ini memberikan nilai yang mendalam bagi kedua subjek agar tidak lagi menyiakan kesempatan yang telah Allah berikan dengan cara mengubah pola hidup lebih baik lagi dan berkeinginan untuk merealisasikan makna tersebut. Sedangkan pada subjek ke US, pandangan subjek bahwa sakit yang dideritanya ini merupakan takdir yang harus dijalani tetapi tidak lagi membuat perubahan dirinya untuk melakukan suatu usaha kembali demi tercapainya kesembuhan dan berputus asa dengan kondisinya saat ini. 
Tahap keempat adalah tahap realisasi makna. Pada tahap ini, individu akan mengalami semangat dan gairah dalam hidupnya, kemudian secara sadar melakukan keikatan diri (self-commitment) dan melakukan kegiatan nyata yang lebih terarah guna memenuhi makna hidupnya. Terlihat sekali pada subjek RT dan WS bahwa kedua subjek merealisasikan hikmah dan pelajaran yang telah mereka ambil dengan cara menentukan sikap dan berkomitmen untuk melakukan perubahan ke arah yang lebih positif. Sikap tersebut ditunjukkan dengan menjalani berbagai pengobatan seperti minum obat teratur, menjaga pola makan, mulai berlatih berjalan (fisioterapi), dan menjaga pikiran berlebih demi tercapainya kesembuhan tersebut.

Subjek US memutuskan hal yang lain dengan kedua subjek lainnya yaitu saat ini subjek memasrahkan segala kondisi dan keadaannya kelak kepada Allah SWT. Memang baik jika individu memasrahkan dirinya kepada Tuhan diiringi dengan usaha. Tetapi berbeda dengan pasrah yang dimaksudkan subjek, saat ini subjek pasrah dikarenakan kondisinya saat ini tidak lagi menunjukkan perubahan ke arah yang lebih baik dan memilih untuk tidak melakukan usaha penyembuhan apa pun.

Tahap terakhir dalam proses penemuan makna hidup ialah tahap kehidupan bermakna. Keberhasilan dalam menemukan dan memenuhi makna hidup akan menyebabkan seseorang merasakan yang berarti dan pada akhirnya akan menimbulkan rasa bahagia. Pada ketiga kasus yang diteliti, menunjukkan bahwa subjek ke RT dan WS berhasil menemukan makna hidup di balik penderitaan yang harus mereka lalui. Sedangkan pada subjek US menunjukkan bahwa subjek tidak dapat mengubah kondisi penderitaan menjadi lebih bermakna sehingga subjek merasakan bahwa saat ini dirinya putus asa dengan keadaannya saat ini dan tanpa tujuan hidup yang jelas. Hal tersebut sejalan dengan pernyataan Frankl (dalam Bastaman, 2007) bahwa seorang individu yang tidak berhasil mengubah kondisi yang tidak bermakna menjadi lebih bermakna maka akan merasakan hidupnya berjalan tanpa tujuan yang jelas dan pada akhirnya akan mengalami penghayatan yang tidak bermakna (meaningless).

Selain tahapan proses penemuan makna hidup, pada penelitian ini juga dibahas pula tentang faktor-faktor apa saja yang memengaruhi insan pasca stroke dalam meraih makna hidup. Faktor yang memengaruhi makna hidup tersebut dibagi menjadi dua yaitu faktor internal dan faktor eksternal. Adapun faktor internal yang ditemukan dalam penelitian ini ada empat yaitu pola berpikir, pola sikap, konsep diri, dan ibadah. Faktor internal yang pertama adalah pola berpikir. Kecenderungan berpikir seseorang baik secara positif atau negatif akan membawa pengaruh terhadap penyesuaian diri dan kehidupan psikisnya. Hal ini berpengaruh pula pada kondisi yang dialami oleh insan pasca stroke. Pola pikir yang positif akan membuat individu menjadi semakin semangat dan termotivasi untuk berusaha mengubah kondisi penderitaan menjadi kondisi yang bermakna (meaningfull). 
Dari ketiga kasus yang telah diteliti, pada subjek RT dan WS ditemukan bahwa pola pikir positif yang mereka terapkan dalam kondisi stroke seperti ini dapat membawa mereka ke dalam ketenangan dan ketegaran agar bisa terus berjuang mencapai kesembuhan. Sedangkan pada subjek US, pola pikir negatif yang dikembangkan oleh subjek tentang kematian membuat dirinya menjadi semakin terpuruk.

Faktor internal kedua yang dapat memengaruhi makna hidup seseorang yaitu pola sikap. Dengan mengubah sikap diharapkan beban mental akibat penderitaan dapat berkurang, bahkan mungkin saja dapat memberikan pengalaman berharga bagi penderita yang disebut dengan hikmah. Pada ketiga kasus yang telah diteliti ditemukan bahwa pada subjek RT dan WS dapat mengambil sikap dari penyakit stroke ini dengan cara mengubah pola hidup lebih sehat dan mendekatkan diri kepada Allah.

Hal ini menjadi salah satu faktor bagi subjek ke RT dan WS agar dapat memperoleh hikmah melalui penyakit stroke yang telah diderita. Sedangkan pada subjek ketiga, tidak adanya sikap yang diambil oleh subjek membuat subjek menjadi pasrah dan menyerahkan segalanya kepada Allah SWT tanpa berusaha untuk melakukan usaha kembali secara maksimal.

Konsep diri yang positif akan mewarnai cara pikir, pola sikap, corak penghayatan dan ragam perbuatan yang positif, demikian pula sebaliknya. Hal ini terlihat pada kasus subjek WS, di mana subjek yakin dan percaya akan kemampuan dirinya untuk tetap kuat dan bertahan dalam menghadapi penyakit stroke yang telah diderita. Pernyataan tersebut dibuktikan oleh kondisi subjek yang masih tetap bertahan sampai sekarang walaupun sudah terserang stroke sebanyak 3 kali.

Menjalani hidup sesuai tuntunan agama memberikan corak penghayatan bahagia dan bermakna bagi seseorang seperti shalat, berdzikir, berpuasa, dan menjalankan ibadah-ibadah lainnya yang diperintahkan oleh Allah. Dari ketiga kasus dalam penelitian ini, ketiga subjek menjalankan ibadah yang telah diperintahkan Allah SWT.

Walaupun begitu, tetap ada perbedaan antara subjek RT dan WS dengan subjek US, di mana kedua subjek tersebut melakukan ibadah beriringan dengan sikap yang mereka ambil demi terpenuhinya makna dalam hidupnya. Sedangkan pada subjek US, subjek menjalankan ibadah untuk memasrahkan dirinya kepada Allah SWT tanpa adanya usaha untuk memperoleh kesembuhan kembali (putus asa).

Sedangkan faktor eksternal yang ditemukan di dalam penelitian ini ada tiga yaitu pekerjaan, hubungan dalam keluarga, dan dukungan sosial. Dengan bekerja individu dapat mengaktualisasikan dirinya. Tetapi dengan bekerja tidak dengan sendirinya akan memberikan makna bagi yang melakukannya. Dari ketiga subjek yang telah diteliti ditemukan bahwa pada subjek RT tanggung jawab pekerjaan menjadi faktor terbesar subjek untuk tetap semangat dan bertahan agar bisa meyelesaikan 
tanggung jawab dalam pekerjaannya. Berbeda halnya dengan subjek US, di mana subjek sebagai laki-laki yang berperan menjadi tulang punggung keluarga menjadi merasakan kehilangan akibat terserang stroke. Hal ini juga menjadi penyebab subjek merasa dirinya sudah tidak berguna dan tidak bermakna lagi.

Kemudian adalah faktor eksternal lain yang memengaruhi seseorang dalam menemukan makna hidup adalah hubungan dalam keluarga. Hal ini berhubungan erat dengan bagaimana seseorang diterima, berperan dan dibutuhkan di dalam keluarganya. Individu yang diterima dengan baik dalam keluarga akan merasakan hidup yang penuh arti dan bahagia. Dalam ketiga kasus pada penelitian ini, ditemukan bahwa faktor hubungan dalam keluarga mempunyai pengaruh yang besar dalam proses penemuan makna hidup setiap subjek.

Dengan diterimanya subjek RT dan WS di dalam keluarga menjadi motivasi tersendiri bagi mereka untuk terus berkomitmen menjalani pemulihan demi tercapainya semua tujuan yang diharapkan masing-masing subjek. Sedangkan pada subjek US penerimaan subjek di dalam keluarga sebenarnya baik dari tahun pertama sampai tahun keempat subjek menjalani sakit stroke ini. Tetapi di tahun kelima ini, penerimaan keluarga terhadap subjek mulai berkurang dikarenakan rasa jenuh dan bosan yang dihadapi keluarga dalam merawat kondisi subjek yang tidak menunjukkan perubahan ke arah yang lebih baik.

Selain itu, dukungan sosial juga mempunyai peran penting dan berarti bagi diri individu. Individu yang dapat berperan penuh dan diterima dengan baik oleh lingkungannya akan merasakan bahagia dan juga penuh semangat melakukan hal-hal untuk kemajuan lingkungan masyarakatnya. Adanya dukungan dan motivasi dari lingkungan sekitar dapat mendorong subjek RT dan WS demi tercapainya kesembuhan subjek. Sedangkan rasa jenuh dan bosan yang dihadapi lingkungan subjek US saat merawat subjek dalam waktu yang relatif lama membuat dukungan sosial yang diberikan pada subjek menjadi menurun dan lama-lama hilang.

\section{SIMPULAN DAN SARAN}

\section{Simpulan}

Penelitian ini bertujuan untuk melihat bagaimana gambaran penemuan makna hidup pada insan pasca stroke. Selain itu, peneliti juga ingin melihat faktor apa sajakah yang memengaruhi insan pasca stroke dalam menemukan makna hidup. 
Berdasarkan uraian analisis di atas dapat disimpulkan bahwa dua dari ketiga subjek dalam penelitian ini mencapai kebermaknaan hidup (meaningfull), sedangkan satu subjek lagi tidak mencapai kebermaknaan hidup (meaningless). Masing-masing subjek diawali dengan penderitaan yang disebabkan oleh perubahan-perubahan yang terjadi dari serangan stroke seperti kelumpuhan, bergantung dengan orang lain, kehilangan pekerjaan, dan isolasi dari lingkungan sekitar. Dari penderitaan tersebut masingmasing subjek memulai tahapan proses penemuan makna hidup sesuai dengan teori yang dikemukakan oleh Bastaman (1996). Walaupun dalam kenyataannya tidak semua subjek mengalami semua tahapan proses tersebut. Pemaknaan hidup yang berhasil dihayati oleh subjek ke I dan II dilalui dengan cara memaknai penyakit stroke ini sebagai takdir dan teguran dari Allah SWT yang memberikan hikmah mendalam agar kedua subjek dapat memperbaiki diri lebih baik lagi.

Selain itu, kondisi tersebut dapat diubah oleh subjek I dan II didukung oleh faktor-faktor yang memengaruhi penemuan makna hidup seseorang. Antara faktor internal dengan faktor eksternal pada kedua subjek tersebut terlihat seimbang dan mempunyai pengaruh yang positif ke dalam setiap tahapan proses yang dilalui subjek. Sedangkan faktor-faktor untuk mencapai kebermaknaan hidup pada subjek ketiga mempunyai pengaruh negatif yang menyebabkan subjek tidak dapat mengubah kondisi stroke yang ada menjadi lebih bermakna.

\section{Saran Teoretis}

Untuk penelitian selanjutnya yang tertarik meneliti lebih lanjut tentang kebermaknaan hidup pada insan pasca stroke diharapkan dapat memerhatikan juga tempat di mana penelitian dilaksanakan. Kemungkinan perbedaan tempat penelitian seperti di klub atau komunitasi penderita stroke akan memengaruhi pula hasil kebermaknaan hidup.

Melihat variabel kebermaknaan hidup yang cukup luas diharapkan penelitian selanjutnya dapat memperbanyak literatur-literatur yang menjelaskan teori-teori tentang kebermaknaan hidup tidak hanya dari Frankl atau Bastaman saja, melainkan juga dari ahli yang lain.

\section{Saran Praktis}

Diharapkan dengan penyakit stroke ini, insan pasca stroke dapat lebih memaknai hidupnya dengan cara melakukan kegiatan yang dapat menunjang proses penyembuhan seperti fisioterapi, terapi wicara, berekreasi dengan keluarga, bersosialisasi dengan lingkugan sekitar, dan dapat memandang masalah dari sudut pandang yang positif. 
Selanjutnya, disarankan agar insan pasca stroke dapat meningkatkan kepercayaan dan ibadahnya kepada Tuhan dikarenakan melalui perenungan diri kita dengan Tuhan akan menjadi salah satu cara agar kita dapat memperoleh makna dari kehidupan ini. Berikutnya, untuk keluarga insan pasca stroke diharapkan dapat terus memberikan pendampingan dan motivasi kepada insan pasca stroke demi tercapainya kesembuhan.

\section{REFERENSI}

Bastaman, H.D. (1996). Meraih hidup bermakna: Kisah pribadi dengan pengalaman tragis. Jakarta: Paramadina.

Bastaman, H. D. (2007). Logoterapi: Psikologi untuk menemukan makna hidup dan meraih hidup bermakna. Jakarta: RajaGrafindo Persada.

Frankl, V. (2008). Optimisme di tengah tragedi: Analisis logoterapi. Bandung: Nuansa.

Feigin, V. (2004). Stroke: Panduan bergambar tentang pencegahan dan pemulihan stroke. Jakarta: Bhuana Ilmu Populer.

Kuncar. (2012). Hubungan antara berpikir positif dengan kebermaknaan hidup pada penderita ketergantungan narkoba (Skripsi tidak dipublikasikan). Universitas Islam Indonesia, Yogyakarta.

Pandji, D. (2011). Stroke bukan akhir segalanya. Jakarta: Elex Media Komputindo.

Papalia, D. E., Olds, S. W., \& Felfdman, R. D. (2009). Human Development Edisi 10:Perkembangan Manusia Buku 2. Editor:Resthi Widyaningrum, Jakarta:Salemba Humanika.

Poerwandari, E. K. (2013). Pendekatan kualitatif untuk penelitian perilaku manusia. Depok: LPSP3 Universitas Indonesia.

Sutrisno, A. (2007). Stroke??? You Must Know Before You Get It! Jakarta: Gramedia Pustaka Utama.

Tirtawati, K. (2008). Locus of control pada insan pasca stroke usia 40- 65 Tahun. E-Journal Gunadarma. Ditemu kembali dari http://publication.gunadarma.ac.id/handle/123456789/1594 